\title{
Characterization of Denitrifying and Dissimilatory Nitrate Reduction to Ammonium Bacteria Isolated from Mud Crab Culture Environment
}

\author{
Yuni Puji Hastuti ${ }^{1}$, Iman Rusmana ${ }^{2}$, Kukuh Nirmala ${ }^{1}$, Ridwan Affandi $^{3}$, and Yuli Siti Fatma ${ }^{2}$ \\ ${ }^{1}$ Department of Aquaculture, ${ }^{2}$ Department of Biology, ${ }^{3}$ Department of Aquatic Resources Management, IPB University, Bogor 16680, \\ Indonesia
}

Received: December 1, 2020 / Revised: April 27, 2021 / Accepted: May 18, 2021

\begin{abstract}
Microbial community plays important roles in the culture environment of mud crab Scylla serrata. One of the environmental management efforts for the cultivation of S.serrata is by stabilizing microorganisms involved in nitrogen cycle process. The availability of dissolved inorganic nitrogen in its culture environment under a recirculating system closely relates to the nitrogen cycle, which involves both anaerobic and aerobic bacterial activities. Anaerobically, there are two major nitrogen compound degradation processes, i.e., denitrification and dissimilatory nitrate reduction to ammonium (DNRA). This study aimed to identify denitrifying and DNRA bacteria isolated from the recirculating cultivation of $S$. serrata. The water samples were collected from anaerobic filters called close filter system, which is anaerobically conditioned with the addition of varying physical filter materials in the recirculating mud crab cultures. The results showed that three denitrifying bacterial isolates and seven DNRA bacterial isolates were successfully identified. The phylogenetic analysis based on 16S rRNA gene of the denitrifying bacteria revealed that HIB_7a had the closest similarity to Stenotrophomonas daejeonensis strain MJ03. Meanwhile, DNRA bacterial isolate of HIB_92 showed a $100 \%$ similarity to Bacillus sonorensis strain N3, Bacillus vallismortis strain VITS-17, Bacillus tequlensis strain TY5, Geobacillus sp. strain DB24, Bacillus subtilis strain A1, and Bacillus mojavensis strain SSRAI21. This study provides basic information denitrifying and DNRA bacterial isolates identity which might have the potential to be applied as probiotics in aquaculture systems in order to maintain optimal environmental conditions.
\end{abstract}

Keywords: Aquaculture environment, bacterial identification, denitrification, DNRA, Scylla serrata, 16S rRNA gene

\section{Introduction}

Mud crab (Scylla serrata) is an important fishery commodity in terms of economic value. In Indonesia, the fattening mud crab production has been conventionally carried out in ponds using crab box or cage culture at a density of one crab per box. Meanwhile, the demand for mud crabs has increased and it becomes a major

*Corresponding author

Tel.: +62-813-1049-9728

E-mail:yuniha@apps.ipb.ac.id export fishery commodity [1]. Thus, it is necessary to develop mud crab cultivation techniques, such as recirculating system, allowing to re-use the water continuously after physical, chemical, and biological filtration [2]. The recirculating system is carried out by continuous water utilization during the cultivation period, so microbial roles in the system are necessary to manage and minimize organic-inorganic waste in the water. The microbial activities maintain the water quality, supporting the mud crab production [3].

Microbes play an important role as the biological filter, which are able to degrade inorganic nitrogen waste 
derived from uneaten feeds and metabolic products of mud crabs, such as feces and urine. Nitrogenous in aquaculture environment is transformed by microbes into several forms, such as ammonia, nitrite, and nitrate. These forms of nitrogen, in certain concentration, are potentially toxic to farmed mud crabs. Therefore, they should be removed from aquaculture environment using bacterial activities, including nitrifying, denitrifying, and DNRA (Dissimilatory Nitrate Reduction to Ammonium) bacteria. The activity of nitrifying, denitrifying and DNRA bacteria could be quantified, providing meaningful information associated with oxidation and reduction activities of dissolved inorganic nitrogen (DIN) [4, 5]. Anaerobically, denitrification and DNRA constitute the main process in the degradation of nitrogenous compounds. Denitrification promotes the biological conversion of nitrate $\left(\mathrm{NO}_{3}{ }^{-}\right)$to nitrite $\left(\mathrm{NO}_{2}{ }^{-}\right)$, nitric oxide (NO), nitrous oxide $\left(\mathrm{N}_{2} \mathrm{O}\right)$ and dinitrogen molecules $\left(\mathrm{N}_{2}\right)$ [4]. Nitrite can serve as an electron acceptor in anaerobic conditions for denitrifying bacteria, which was then reduced into $\mathrm{N}_{2} \mathrm{O}$ and $\mathrm{N}_{2}[4,6]$. During the anaerobic condition, DNRA bacteria convert nitrate into nitrite and then ammonium through a dissimilative process. The DNRA reaction could be present despite a low concentration of nitrate and a high level of carbon [7].

A previous study reported that indigenous oligotrophic bacteria have a desirable nitrogen removal activity in the water reservoir. Application of indigenous denitrifying bacteria could reduce nitrate content from $1.71 \pm 0.01 \mathrm{mg} / \mathrm{l}$ to $0.80 \pm 0.06 \mathrm{mg} / \mathrm{l}$ and remove total nitrogen up to $38.33 \pm 1.50 \%$ [8]. The use of indigenous microorganisms with favorable activities and culturabilities is expected to eliminate harmful inorganic nitrogen compounds in the aquaculture environment system.

To obtain initial scientific evidence of indigenous bacteria in the farming system, identifying and characterizing the denitrifying and DNRA bacteria are needed to be performed in mud crab farming. Their presence may serve as a bioindicator of the suitability and stability of water quality in the rearing water. This present study aimed to identify and characterize denitrifying and DNRA bacteria in the mud crab farming facilities under a recirculating technology. Identifying bacterial isolates would be a beneficial step to classify and apply them in aquaculture activities.

\section{Materials and Methods}

Mud crabs $S$. serrata were obtained from the coastal area in two locations, i.e., Banjarmasin (South Kalimantan) and Pasuruan (East Java) and the mud crab catches is assisted by local fishermen. This research was conducted at the Faculty of Fisheries and Marine Science, Faculty of Mathematics and Natural Science, and Faculty of Veterinary Medicine, IPB University, Indonesia.

\section{Preparation of recirculating system for mud crab culture}

Mud crabs (10 individuals) were parallelly reared in $60 \mathrm{~L}$ seawater with a salinity of $25 \mathrm{~g} / \mathrm{l}$. The recirculating system was equipped with six shelters (a total area of $220 \mathrm{~cm}^{2}$ ) at a density of 10 mud crabs $[9,10]$. Two filter

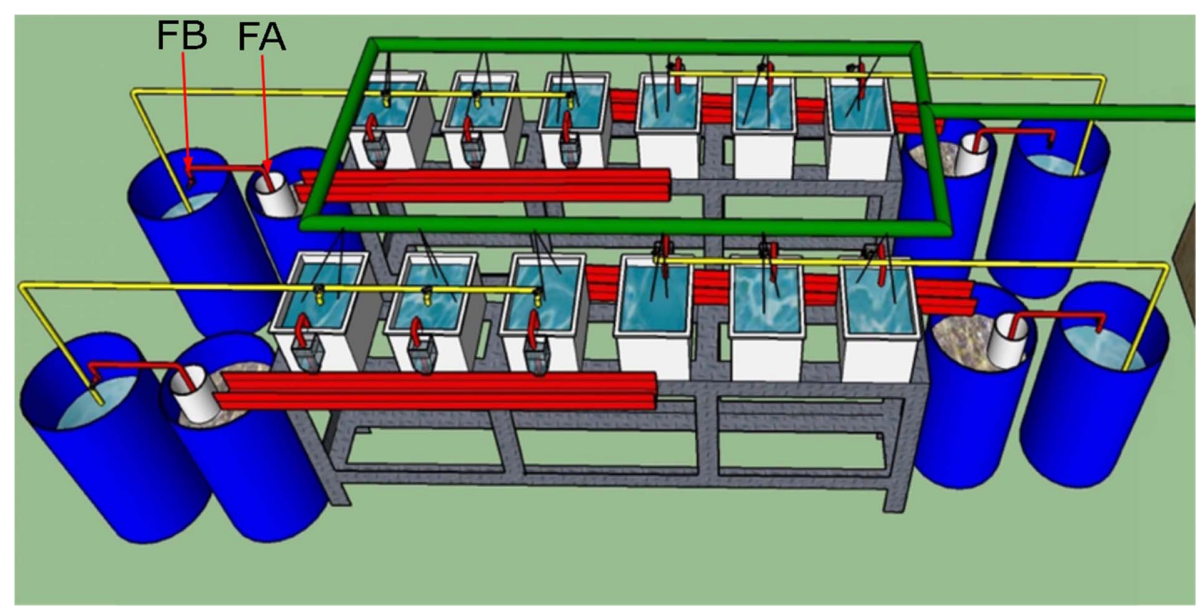

Fig. 1. Mud crab recirculating culture system and the filters: close filter system (FA) and open filter system (FB). 
Table 1. The composition of the culture medium for denitrifying and DNRA bacteria.

\begin{tabular}{|c|c|c|c|}
\hline \multicolumn{2}{|c|}{ Denitrification specific medium } & \multicolumn{2}{|c|}{ DNRA specific medium } \\
\hline Composition & Concentration $(\mathrm{g} / \mathrm{l})$ & Composition & Concentration $(\mathrm{g} / \mathrm{l})$ \\
\hline $\mathrm{Na}_{2} \mathrm{HPO}_{4}$ & 0.9 & $\mathrm{Na}_{2} \mathrm{HPO}_{4}$ & 0.9 \\
\hline $\mathrm{KH}_{2} \mathrm{PO}_{4}$ & 0.2 & $\mathrm{KH}_{2} \mathrm{PO}_{4}$ & 0.2 \\
\hline $\mathrm{MgSO}_{4} \cdot 7 \mathrm{H}_{2} \mathrm{O}$ & 0.1 & $\mathrm{MgSO}_{4} \cdot 7 \mathrm{H}_{2} \mathrm{O}$ & 0.1 \\
\hline $\mathrm{FeCl}_{3} \cdot 6 \mathrm{H}_{2} \mathrm{O}$ & 0.005 & $\mathrm{FeCl}_{3} \cdot 6 \mathrm{H}_{2} \mathrm{O}$ & 0.005 \\
\hline $\mathrm{CaCl}_{2} \cdot 6 \mathrm{H}_{2} \mathrm{O}$ & 0.0184 & $\mathrm{CaCl}_{2} \cdot \mathrm{H}_{2} \mathrm{O}$ & 0.0184 \\
\hline $\mathrm{NaNO}_{3}$ & 0.025 & $\mathrm{NaNO}_{3}$ & 0.5 \\
\hline Yeast extract & 0.25 & Yeast extract & 0.125 \\
\hline Carbon source : acetate & 5 & Carbon source: glucose & 5 \\
\hline
\end{tabular}

tanks applied in this study were a close filter system (FA) and an open filter system (FB). FA was consisted of varying physical filter materials arranged in order from bottom to top, including 250 bioballs, $40 \mathrm{~kg}$ zeolite, $90 \mathrm{~kg}$ sands, 800-1200 bioballs, and 4 layer gauze. FB was made from 3-layer corrugated fiber $\mathrm{FB}$ was made from 3-layer corrugated fiber. The water capacity of FA and FB was $220 \mathrm{~L}$ with a water debit of $0.125 \mathrm{~L} \mathrm{~s}^{-1}$ and a pump capacity of $200 \mathrm{~V}$, respectively (Fig. 1).

\section{Isolation and purification of denitrifying and DNRA bacteria}

FA tanks were filled with various physical filter materials to support anaerobic condition in the filter, so denitrifying and DNRA bacteria are considered to be commonly found in that filter. For bacterial isolation, water samples were collected from four FA tanks. Subsequently the same amount of water samples from those four FA tanks were well mixed to obtain a composite water sample. The composite water sample was serially diluted in $\mathrm{NaCl} 0.85 \%$ solution $\left(10^{-1}, 10^{-2}, 10^{-3}, 10^{-4}\right.$, and $10^{-5}$ ), spread on denitrification and DNRA selective media, respectively (Table 1) [11]. The media were anaerobically incubated at room temperature for 7-14 days in an anaerobic jar using an anaerobic jar kit for oxygen reduction. Bacterial isolates purification was carried out using the culture media, incubation time, and incubation condition which was similar to the bacterial isolation step.

\section{Characterization of denitrifying and DNRA bacteria}

The bacterial pure cultures were characterized by oxidative/fermentative test (OF test) using Hugh and
Leifson method [12] and Gram staining [13]. OF test were carried out on denitrifying and DNRA bacterial pure culture to determine the oxidative and fermentative bacterial groups using Hugh and Leifson's OF medium which contain glucose, peptones, and bromothymol blue indicator [12].

\section{S rRNA gene sequencing}

Selected isolates of denitrifying and DNRA bacteria were identified using the molecular technique. Bacterial genomic DNA was extracted using Presto ${ }^{\text {TM }}$ Mini gDNA Kit (Geneaid Biotech Ltd, Taiwan) according to manufacturer's procedures. The concentration and purity of DNA were determined using Nanodrop 2000 (Thermo Scientific, USA). Furthermore, the 16S rRNA gene of denitrifying and DNRA bacteria was amplified using a PCR primer set 63F (5'-CAG GCC TAA CAC ATG CAA GTC-3') and 1387R (5'-GGG CGG WGT GTA CAA GGC3 ) with the expected band size of approximately 1,400 bp [14]. PCR mixture with a total volume of $25 \mu$ l contained $12.5 \mu \mathrm{l}$ of GoTaq Green Master Mix 2X (Promega, USA) or MyTaq ${ }^{\mathrm{TM}}$ Red Mix (Bioline, UK), $2.5 \mu \mathrm{l}$ of each primer $63 \mathrm{~F}$ and $1387 \mathrm{R}$ with a concentration of $10 \mathrm{pmol}, 6.5 \mu \mathrm{l}$ of nuclease-free water, and $1 \mu \mathrm{l}$ of genomic DNA template. The PCR reaction was carried out in $95^{\circ} \mathrm{C}$ for 5 min (predenaturation), followed by 35 cycles of $95^{\circ} \mathrm{C}$ for $15 \mathrm{~min}$ (denaturation), $55^{\circ} \mathrm{C}$ for $1 \mathrm{~min}$ (annealing), $72^{\circ} \mathrm{C}$ for 1.5 min (extension), and $72^{\circ} \mathrm{C}$ for $10 \mathrm{~min}$ (post-extension). The PCR products were confirmed using electrophoresis in $0.8 \%(\mathrm{w} / \mathrm{v})$ agarose gel for $45 \mathrm{~min}$ at $80 \mathrm{~V}$ and were visualized using UV transilluminator with ethidium bromide staining. The selected PCR products were sequenced by a DNA sequencing service, $1^{\text {st }}$ BASE DNA 
Sequencing Services. DNA sequences of denitrifying and DNRA bacterial isolates were separately compared to GenBank using BLAST-N (Basic Local Alignment Search Tool - Nucleotide) software in NCBI (National Center for Biotechnology Information). The phylogenetic tree was constructed using MEGA 6.00 by Neighbor Joining method with Bootstrap 2000×.

\section{Results and Discussion}

\section{Denitrifying and DRNA bacteria isolated from mud crab culture under a recirculating system}

A total of 112 isolates of denitrifying bacteria and 166 isolates of DNRA bacteria were obtained from denitrification and DNRA bacterial growth medium, respectively (Table 2). Based on growth rate and contaminant-free culture, we successfully obtained a total of 180 selected isolates, consisting of 88 denitrifying bacterial isolates and 92 DNRA bacterial isolates. All bacterial isolates were screened through the oxidative and fermentative (OF) test. Bacterial isolates with oxidative and fermentative activities were categorized as denitrifying and DNRA bacteria, respectively. We obtained 12 denitrifying bacterial isolates and 14 DNRA bacterial isolates.
Finally, through the OF test, we selected three denitrifying bacterial isolates and seven DNRA bacterial isolates, which were then identified by phylogeny using $16 \mathrm{~S}$ rRNA gene sequencing.

The Gram stain test indicated that the bacterial cells are rod-shaped, Gram-positive, and Gram-negative bacteria (Table 3). The morphology of HIB_7a isolate appeared as a big colony, pale white, and circular form, while the cells were rod-shaped and Gram-negative. As mentioned by Yu et al. [15], denitrifying bacterial colonies commonly have the following characteristics, i.e., white, irregular, rod-shaped cells, and Gram-negative cells. Colony morphology of DNRA bacteria (HIB_27, HIB_95, and HIB_96) demonstrated with yellowish-white and whitish yellow, flat and convex elevation, while the bacterial cells had cocci and bacil shape, and Gram-positive stain. Some bacterial cells had similar characteristics to Bacillus. Also, the type of bacteria is mostly capable of exhibiting fermentation activities as performed by DNRA bacteria.

\section{Phylogenetic analysis of denitrifying bacteria based on 16S rRNA gene}

As exhibited by the phylogenetic tree in Fig. 2, HIB_7a

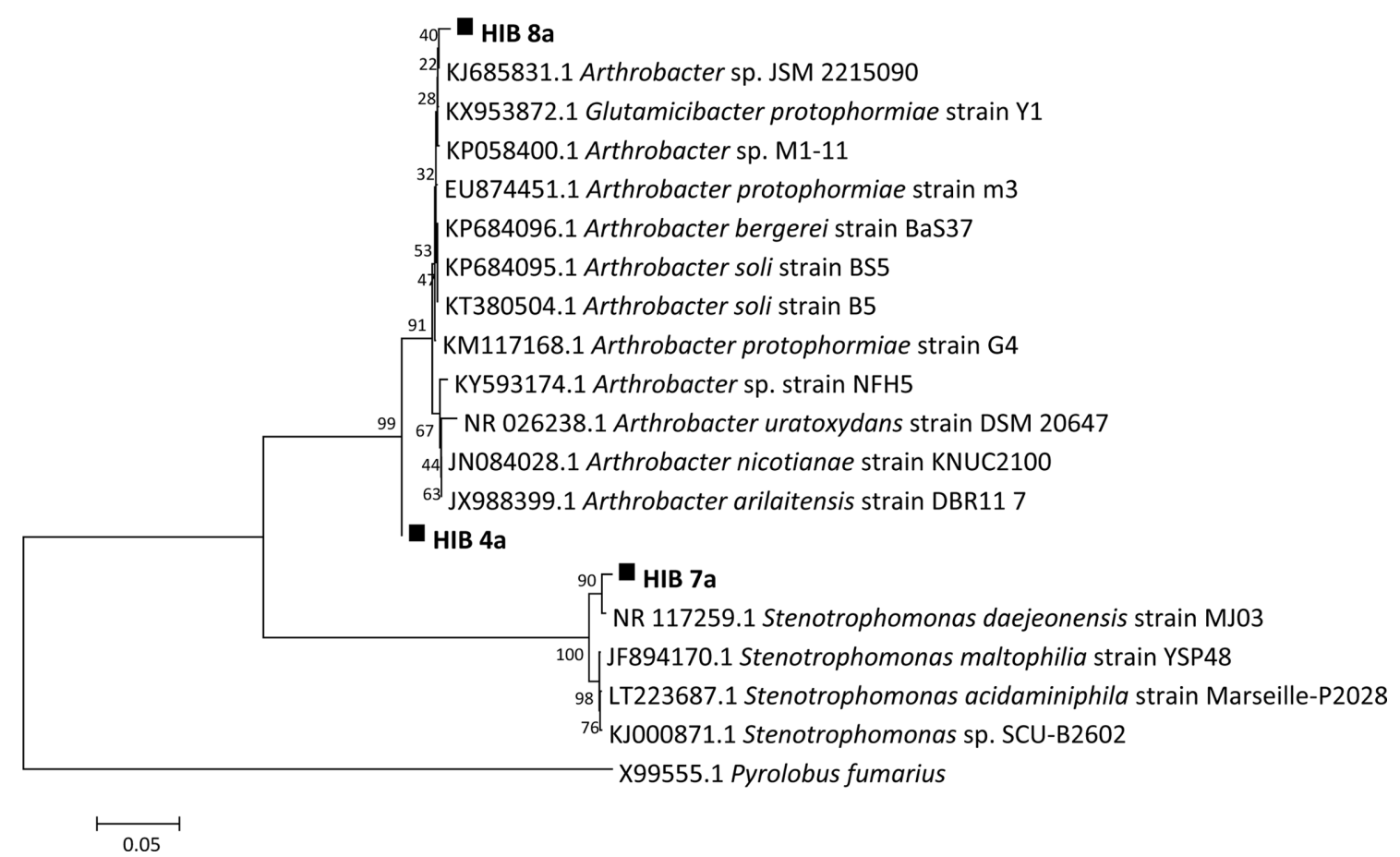

Fig. 2. Phylogenetic tree of denitrifying bacteria isolated from mud crab culture under a recirculating system using Kimura 2-parameter model with 2000x Bootstrap. 
Table 2. Denitrifying and DNRA bacteria isolated from mud crab culture under a recirculating system.

\begin{tabular}{ccccc}
\hline Type of bacteria & Number of isolates & $\begin{array}{c}\text { Number of isolates } \\
\text { by their growth }\end{array}$ & $\begin{array}{c}\text { Number of isolates by their } \\
\text { metabolic activities } \\
\text { (oxidative and fermentative test) }\end{array}$ & $\begin{array}{c}\text { Number of selected isolates } \\
\text { by their specific activity }\end{array}$ \\
\hline Denitrification & 112 & 88 & 12 & 3 \\
DNRA & 166 & 92 & 14 & 7 \\
Total & 278 & 180 & 26 & 10 \\
\hline
\end{tabular}

belongs to Stenotrophomonas sp. BLAST-N analysis revealed that the denitrifying bacterial isolate demonstrated 99\% similarity to Stenotrophomonas daejeonensis strain MJ03. Stenotrophomonas enables to perform $\mathrm{NO}_{3}$ reduction reaction, but generates $\mathrm{NO}_{2}$ as an end product [16], such as Stenotrophomonas maltophilia [17]. In terms of morphological, biochemical, and molecular characteristics based on the 16S rRNA gene, we observed two groups of denitrifying bacteria existed in the marine ecosystem, i.e., Stenotrophomonas sp. and Oceanimonas sp. YC13 [15]. Stenotrophomonas strain had been reported to have a better activity, classified as marine denitrifier, and ever found together with another denitrifying bacterium Oceanimonas denitrificans F13-1 (DQ097665) [15]. According to the analysis using BLAST-N, HIB_8a and HIB_4a isolates had the closest similarity to Arthrobacter. Arthrobacter arilaitensis strain Y-10 is an aerobic denitrifier, which is able to reduce ammonium, nitrite, and nitrate up to $65 \%, 100 \%$, and $61.2 \%$, respectively [18]. Moreover, Denitromonas had been reported to take part in the denitrification process and often exist in mud and saline water [19, 20].

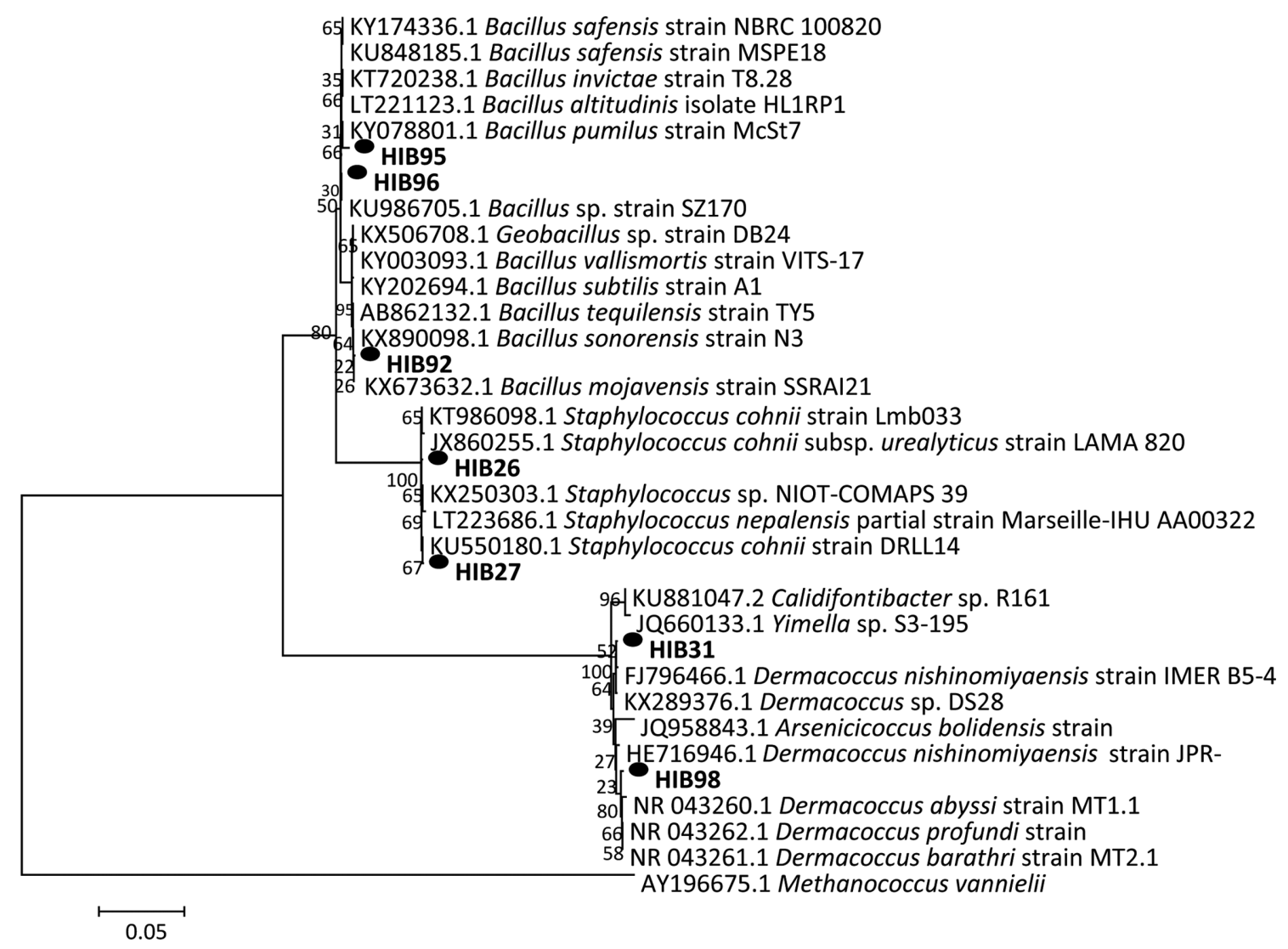

Fig. 3. Phylogenetic tree of DNRA bacteria isolated from mud crab culture under a recirculating system using Kimura 2parameter model with $2000 \times$ Bootstrap. 


\section{Identification of DNRA bacteria based on 16S rRNA gene}

Our results showed that DNRA bacterial isolates had an average similarity percentage of $100 \%$ to genus Bacillus, Staphylococcus, Arsenicicoccus, and Dermacoccus (Fig. 3). Furthermore, the alignment step is carried out to identify the conserved sequence between DNA bands of each isolate and those from GenBank. Nucleotide sequence obtained from BLAST-N was translated into amino acid sequence. The amino acids sequences were confirmed using the Conserved Domain Database software (http://www.ncbi.nlm.nih.gov/Structure/cdd/ wrpsb.cgi) to obtain the resulting domain [21]. Meanwhile, the phylogenetic tree of denitrifying and DNRA bacteria isolated from mud crab culture facilities was constructed using a Neighbor-Joining tree by MEGA 6 software [22] with Kimura-2-parameter, 2000× Bootstrap, and determined by the lowest BIC (Bayesian Information Criterion) value.

Phylogenetic tree of DNRA bacteria demonstrated that the isolates showed similarity to some bacterial species database stored in GenBank. HIB_92 isolate was found to have $100 \%$ similarity to Bacillus sonorensis strain N3, Bacillus vallismortis strain VITS-17, Bacillus tequilensis strain TY5, Geobacillus sp. strain DB24, Bacillus subtilis strain A1, and Bacillus mojavensis strain SSRAI21. HIB_96 isolate had 98-100\% similarity to Bacillus safensis strain NBRC 100820, Bacillus pumilus strain McSt7, and Bacillus invictae strain
T8.28 (Fig. 3). Meanwhile, HIB_26 isolate exhibited $100 \%$ similarity to Staphylococcus sp. NIOT-COMAPS 39, Staphylococcus cohnii strain DRLL14, and Staphylococcus nepalensis partial strain Marselle-IHU AA00322.

Phylogenetic analysis with a scale of $5 \%$ suggested that HIB_95 showed 66\% similarity to Bacillus invictae strain T8.28, B. safensis strain MSPE 18, and Bacillus altitudinis isolate HL 1RP1. Furthermore, HIB_27 isolate demonstrated $100 \%$ similarity to $S$. cohnii strain Lmb033 and S. cohnii subsp. urealyticus LAMA 820, while HIB_98 isolate showed similarity to Dermacoccus nishinomiyaensis strain JPR-06, Calidifontibacter sp. R161, Yimela sp. S3-195, Dermacoccus abyssi strain MT1.1, and Dermacoccus profundi strain MT2.2 (Fig. 3). Most DNRA bacterial isolates were nitratereducing bacteria and regarded as fermentative bacteria, in which their activities are dependent on nitrate level in the environment [23]. The nitrate-reducing activity generated by denitrifying and DNRA bacteria is considerably affected by electron donor and carbon sources [5, 24]. The limitation on nitrate level is a crucial factor for the growth of DNRA bacteria, contributing to the continuous process of the nitrate-reducing reaction [25]. In mangrove ecosystem or coastal area, DNRA reaction may exist. It often occurs under the condition in which inorganic nitrogen is trapped in the absence of oxygen [26].

Table 3. Morphological characteristics and OF test of denitrifying and DNRA bacteria isolated from mud crab culture under a recirculating system.

\begin{tabular}{|c|c|c|c|c|}
\hline No. & Isolates & Colony morphology & Cell morphology & OF test \\
\hline \multicolumn{5}{|c|}{ Denitrifying bacteria } \\
\hline 1 & HIB_4a & Big, white, yellowish, circular, mucoid & Rod/Gram + & $\mathrm{O}$ \\
\hline 2 & HIB_7a & Small, white, circular, mucoid & Rod/Gram - & $\mathrm{O}$ \\
\hline 3 & HIB_8a & Big, yellow, oval/circular, mucoid & Rod/Gram + & $\mathrm{O}$ \\
\hline \multicolumn{5}{|c|}{ DNRA bacteria } \\
\hline 1 & HIB_26 & Medium, white, smooth, convex & Cocci/Gram + & $\mathrm{F}$ \\
\hline 2 & HIB_27 & Big, yellowish white, smooth, convex & Cocci/Gram + & $\mathrm{F}$ \\
\hline 3 & HIB_31 & Medium, transparent, less white, smooth, convex & Cocci/Gram + & $\mathrm{F}$ \\
\hline 4 & HIB_92 & Medium, white, smooth, convex & Rod/Gram + & $\mathrm{F}$ \\
\hline 5 & HIB_95 & Small, whitish yellow, smooth, convex, filamentous & Rod/Gram + & $\mathrm{F}$ \\
\hline 6 & HIB_96 & Small, whitish yellow, smooth, convex, filamentous & Rod/Gram + & $\mathrm{F}$ \\
\hline 7 & HIB_98 & Small, yellow, circular, smooth, convex & Cocci/Gram + & $\mathrm{F}$ \\
\hline
\end{tabular}

$\mathrm{O}$ : oxidative; $\mathrm{F}$ : fermentative. 


\section{Conclusion}

Three denitrifying bacterial isolates and seven DNRA bacteria isolates have varying morphological and taxonomic characteristics. The phylogenetic analysis based on the 16S rRNA gene of the denitrifying bacterial isolates revealed that HIB_7a isolate was found to belong to Stenotrophomonas daejeonensis strain MJ03. HIB_92 isolate of DNRA bacteria had a $100 \%$ similarity to $B$. sonorensis strain N3, Bacillus strain VITS-17, B. tequilensis strain TY5, Geobacillus sp. strain DB24, B. subtilis strain A1, and B. mojavensis strain SSRAI21. Denitrifying and DNRA bacteria isolated from mud crab cultivation might be developed for their application as probiotics in the aquaculture environment.

\section{Conflict of Interest}

The authors have no financial conflicts of interest to declare.

\section{References}

1. KKP. 2018. Produktivitas Perikanan Indonesia. Available from https://kkp.go.id/wp-content/uploads/2018/01/KKP-Dirjen-PDSPKPFMB-Kominfo-19-Januari-2018.pdf (Accessed Sep. 1, 2020). (in Indonesian).

2. Shelley C, Lovatelli A. 2011. Mud Crab Aquaculture: A Practical Manual, pp. 22-29. Food and Agriculture Organization of the United Nations, Rome, Italy.

3. Hastuti YP, Rusmana I, Nirmala K, Affandi R. 2017. Activities of $\mathrm{NH}_{4}{ }^{+}$and $\mathrm{NO}_{2}^{-}$oxidizing bacteria in a recirculating system of mud crab (Scylla serrata) culture with different number of shelter. Res. J. Microbiol. 12: 137-145.

4. Zumft WG. 1997. Cell biology and molecular basic of denitrification. Microbiol. Mol. Biol. Rev. 61: 533-616.

5. Giblin A, Tobias C, Song B, Weston N, Banta GT, Rivera-Monroy VH. 2013. The importance of dissimilatory nitrate reduction to ammonium (DNRA) in the nitrogen cycle of coastal ecosystems. Oceanography 26: 124-131.

6. Richardson DJ. 2000. Bacterial respiration: a flexible process for a changing environment. Microbiology 146: 551-571.

7. Kox MAR, Jetten MSM. 2015. The nitrogen cycle, pp. 205-214. In Lugtenberg B (ed.), Principles of Plant-Microbe Interactions. Springer International Publishing, Berlin.

8. Zhou S, Huang T, Zhang H, Zeng M, Liu F, Bai S, et al. 2015. Nitrogen removal characteristic of enhanced in situ indigenous aerobic denitrification bacteria for micro-polluted reservoir source water. Bioresour. Technol. 201: 195-207.

9. Hastuti YP, Rusmana I, Nirmala K, Affandi R. 2017. Activities of $\mathrm{NH}_{4}^{+}$and $\mathrm{NO}_{2}$-oxidizing bacteria in a recirculating system of mud crab (Scylla serrata) culture with different number of shelter. Res. J. Microbiol. 12: 137-145.

10. Hastuti YP, Rusmana I, Nirmala K, Affandi R, Tridesianti S. 2019. Identification and characterization of nitrifying bacteria in mud crab (Scylla serrata) recirculation aquaculture system by $16 \mathrm{~S}$ rRNA sequencing. Biodiversitas 20: 1339-1343.

11. Novita L. 2014. Diversity of bacterial community that contribute in nitrogen cycle at lake of Situ Sawangan-Bojongsari, West Java. Institut Pertanian Bogor, Bogor. (in Indonesia).

12. Hugh R, Leifson EJ. 1953. The taxonomic significance of fermentative versus oxidative metabolism of carbohydrates by various gram negative bacteria. J. Bacteriol. 66: 24-26.

13. Hadioetomo RS. 1983. Mikrobiologi Dasar dalam Praktek. Gramedia Pustaka Utama, Jakarta. (in Indonesian).

14. Marchesi JR, Sato T, Weightman AJ, Martin TA, Fry JC, Hiom SJ, et al. 1998. Design and evaluation of useful bacteria specific PCR primers that amplify genes coding for bacteria $16 \mathrm{~S}$ rRNA. Appl. Environ. Microbiol. 64: 795-799.

15. Yu L, Liu Y, Wang G. 2008. Identification of novel denitrifying bacteria Stenotrophomonas sp. ZZ15 and Oceanimonas sp. YC13 application for removal of nitrate from industrial wastewater. Biodegradation 20: 391-400.

16. Heylen K, Vanparys B, Peirsegaele F. 2007. Stenotrophomonas terrae sp. nov. and Stenotrophomonas humi sp. nov., two nitratereducing bacteria isolated from soil. Int. J. Syst. Evol. Microbiol. 57: 2056-2061.

17. Jafari SJ, Moussavi G, Yaghmaeian K. 2015. High-rate biological denitrification in the cyclic rotating bed biological reactor: effect of $\mathrm{COD} / \mathrm{NO}_{3}{ }^{-}$nitrate concentration and salinity and the phylogenetic analysis of denitrifiers. Bioresour. Technol. 197: 482-488.

18. He TX, Ni JP, Li ZL, Sun Q, Qing Y, Xu Y. 2016. Heterotrophic nitrification and aerobic denitrification of the hypothermia aerobic denitrification bacterium: Arthrobacter arilaitensis. Huan Jing ke Xue. 37: 1082-1088.

19. Babatsouli P, Fodelianakis S, Paranychianakis N, Venieri D, Dialynas M, Kalogerakis N. 2015. Single stage treatment of saline wastewater with marine bacterial-microalgae consortia in a fixed-bed photobioreactor. J. Hazard. Mater. 292: 155-163.

20. Wang B, Gong Y, Huang W, Wang Y, Zhou J. 2017. Bacterial community structure in simultaneous nitrification, denitrification and organic matter removal process treating saline mustard tuber wastewater as revealed by $16 \mathrm{~S}$ rRNA sequencing. Bioresour. Technol. 228: 31-38.

21. Marchler-Bauer A, Derbyshire MK, Gonzales NR, Lu S, Chitsaz F, Geer LY, et al. 2015. CDD: NCBI's conserved domain database. Nucleic Acids Res. 43(Database issue): D222-D226.

22. Tamura K, Stecher G, Peterson D, Filipski A, Kumar S. 2013. MEGA6: Molecular evolutionary genetics analysis version 6.0. Mol. Biol. Evol. 30: 2725-2729.

23. van den Berg EM, Boleij M, Kuenen JG, Kleerebezem R, van Loosdrecht MCM. 2016. DNRA and denitrification coexist over a broad range of acetate/N- $-\mathrm{NO}_{3}{ }^{-}$ratios, in a chemostat enrichment culture. Front. Microbiol. 7: 1842. 
24. Plummer P, Tobias C, Cady D. 2015. Nitrogen reduction pathways in estuarine sediments: Influences of organic carbon and sulfide. J. Geophys. Res. Biogeosci. 120: 1958-1972.

25. van den Berg EM, van Dongen $U$, Abbas B, van Loosdrecht MCM. 2015. Enrichment of DNRA bacteria in a continuous culture. ISME
J. 9: 2153-2161.

26. Deborde J, Marchand C, Molnar N, Patrona LD, Meziane T. 2015. Concentration and fractionation of carbon, iron, sulfur, nitrogen and phosphorus in mangrove sediment along an intertidal gradient (semi-arid climate, New Caledonia). J. Mar. Sci. Eng. 3: 52-72. 